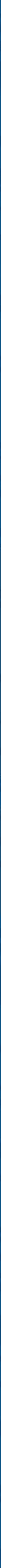




\section{Sumário}

I. Crônicas do Direito Internacional ................................................1

MAPEAMENTO E COMPARAÇÃO DE ACORDOS DE PROTEÇÃO DE INVESTIMENTOS INTERNACIONAIS na América Latina e Central 1990 a 2018 .............................................................. 3

Anderson Fonseca Machado (organizador), Letícia Braga Carvalho Kataoka (organizadora), Ana Terra Teles de Meneses, André Leão, Andrea Luísa de Oliveira, Edilson Enedino das Chagas, Henrique Haruki Arake Cavalcante, Mariana Rezende Maranhão da Costa, Rafael Freitas Machado, Vitor Levi, Wilson Sampaio Sahade Filho

Private International Law Chronicles ....................................................................19

Nadia de Araujo, Marcelo De Nardi, Inez Lopes e Fabrício Polido (org.)

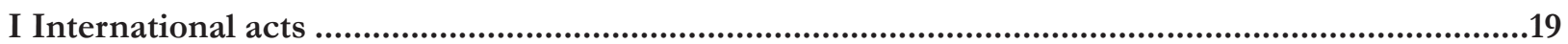

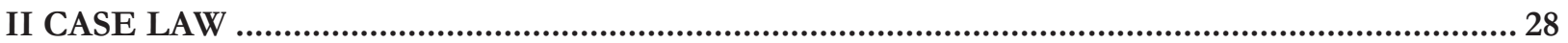

II. Dossiê Especial: Arbitragem e Direito Internacional ..........................35

EL ROL DE LAS INSTITUCIONES ARBITRALES EN EL DESARROLLO DEL ARBITRAJE INTERNACIONAL..... 37 Ivette Esis

REVISITANDO A AVERSÃo BRASILEIRA À CLÁUSULA INVESTIDOR-EsTADO: CAPITALISMO DE EsTADO

E TREATY-SHOPPING

Marcelo Simões dos Reis e Gustavo Ferreira Ribeiro

Arbitral interpretation OF INVESTMENT TREATIES: PROBLEMS AND REMEDIES FOR THE DEBATE ON "LEGITIMACY"

Santiago Díaz-Cediel

Arbitragem Internacional sob Anexo VII da Convenção das Nações Unidas sobre o Direito do Mar e as Controvérsias Mistas: Análise de Casos Recentes

Alexandre Pereira da Silva

Arbitragem de investimentos e o meio ambiente: reflexões sobre o caso Ethyl CorpoRATION V. CANADÁ.

Patrícia Maria da Silva Gomes 
Homologação de SENTENÇA ARBitral ESTRANGEIRA ANULADA NA ORIGEM: o CASo EDF IN-

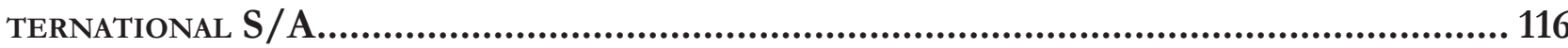

Patrícia Maria da Silva Gomes

II. Artigos sobre outros temas 129

International Constitutional Court: Rise and Fall of an International Debate 131 Arthur Roberto Capella Giannattasio, Taina Ometto Bezerra, Elizabeth Bannwart, Débora Drezza, Jessica Buchler, Giovanna Martins e Breno Oliveira

International Constitutional Court: Rise and Fall of an International Debate 148 Janaína Gomes Garcia de Moraes e Patricio Alvarado

InVestigação histórica do Conteúdo da Concepção de Trabalho Decente no ÂMbito DA OIT E UMA ANÁLISE DE SUA JUSTICIABILIDADE 166 Silvio Beltramelli Neto e Julia de Carvalho Voltani

O DIÁLOGO ENTRE FONTES NORMATIVAS E O CONTROLE DE CONVENCIONALIDADE: ENTRE O LIVRE COMÉRCIO E O DESENVOLVIMENTO ECONÔMICO E SUSTENTÁVEL 187

Eduardo Biacchi Gomes e Julia Colle Marinozzi

O DIREITO INTERNACIONAL DO DESENVOLVIMENTO E SUAS RAÍZES IMPERIALISTAS NO CONTEXTO DO PLURALISMO NORMATIVO: POR UM PARADIGMA LIBERTÁRIO E NÃO (NEO)LIBERAL 201

Lucas Silva de Souza e Jânia Maria Lopes Saldanha

ENTRE O ESCUDO E A ESPADA: CARACTERIZANDO O LAND GRABBING COMO CRIME CONTRA A HUMANIDADE

Rodolfo Soares Ribeiro Lopes

Descolonialismo e o Direito Internacional Privado na América Latina: desvendando NOVOS PARADIGMAS

Eduardo Biacchi Gomes e Luis Alexandre Carta Winter

Criminalização de imigrantes ILEgais Na União Europeia: novos PaRAdigmas COM base nO CASO CELAJ 253

Felipe Augusto Lopes Carvalho 
O CASO INTEL: O IMPACTO NA EVOLUÇÃO DA TEORIA DOS EFEITOS NO DIREITO DA CONCORRÊNCIA DA UNIÃo EUROPEIA...............................................................................270

Augusto Jaeger Junior e Mariana Sebalhos Jorge

The DUTY OF CARE OF PARENT COMPANIES: A TOOL FOR ESTABLISHING A TRANSNATIONAL ENVIRONMENTAL CIVIL LIABILITY

Mathilde Hautereau Boutonnet 


\title{
The duty of care of parent companies: a tool for establishing a transnational environmental civil liability*
}

\author{
O dever de diligência das empresas matrizes: \\ um instrumento para estabelecer uma \\ responsabilidade civil ambiental transnacional
}

Mathilde Hautereau Boutonnet**

\begin{abstract}
The duty of vigilance of parent companies in respect of the environmental damage caused by the activities of their subsidiaries abroad occupies an increasingly important place in various rights. While the legislator came to recognize this duty in French law, the judge offers him a place in Common Law and the companies themselves recognize it in the transnational order. However, this article aims to show how, in complement and interaction, under the action of the legislator, the judge and the addressees of the duty, the bringing into play of the responsibility of the parent companies in a transnational dispute could be facilitated. The duty of care could become an important tool of environmental responsibility.
\end{abstract}

Keywords: Duty of care - French law - Judge - Common Law - National law - Transnational law - Voluntary instruments - Environmental civil liability Transnational litigation - Parent company - Subsidiaries

\section{Resumo}

O dever de vigilância das empresas matrizes referente aos danos ambientais causados pelas atividades de suas subsidiárias no exterior ocupa um lugar cada vez mais importante em vários direitos nacionais. Enquanto o legislador chegou a reconhecer este dever na lei francesa, o juiz oferece-lhe um espaço no Common Law e as próprias empresas reconhecem-no na ordem transnacional. No entanto, este artigo tem como objetivo mostrar como, sob a ação e a articulação do legislador, do juiz e dos destinatários do dever, a responsabilidade das empresas matrizes em uma disputa transnacional poderia ser facilitada. O dever de diligência pode se tornar uma importante ferramenta da responsabilidade ambiental.

Palavras-chave: Diligência, Direito francês, Juiz, Direito nacional, Direito transnacional. 


\section{Introduction}

Our contribution aims to show how the duty of vigilance $^{1}$, or duty of care, of companies that exists in various domestic legal orders, enshrined in legislation or case law, and in the transnational order in the form of "soft law", could lead, if breached and in the context of a transnational dispute, to the establishment of an environmental civil liability for parent companies and thereby contribute to improving environmental protection.

Transnational environmental disputes are complex ${ }^{2}$. This is due, on the one hand, to the relocation of business operations that allows large corporations to carry out their business via subsidiaries based overseas and, on the other hand, to the globalisation of environmental threats, namely the fact that a threat created by a company located in one country A can result in harmful consequences for victims domiciled in another country B. While the former is perfectly exemplified by the Shell decision, where Nigerian citizens and a Dutch NGO sought compensation, before a Dutch court, from the Shell parent company domiciled in the Netherlands and from its Nigerian subsidiary for the environmental harm caused by oil spills in the Niger Delta ${ }^{3}$, the RWE case currently pending before a German court, brought by a Peruvian farmer against German corporation RWE regarding climate damage allegedly caused by the activities of this energy giant domiciled on German soil, is emblematic of the latter ${ }^{4}$.

In this type of dispute, the victims' goal is to bring before the forum court, in addition to the overseas subsidiary if the latter is directly responsible for the prejudice in country $\mathrm{B}$, the parent company domiciled in country A. The extraterritorial reach of the duty of care

S. Schiller (dir.), Le devoir de vigilance, LexisNexis, 2019.

2 See Report : HAUTEREAU-BOUTONNET, M.; TRUILHÉ, E. Le procès environnemental, du procès sur l'environnement au procès pour l'environnement, soutenu par la Mission de Recherche Droit et Justice, 2019. Available in: http://www.gip-recherche-justice. fr/wp-content/uploads/2019/05/16.31-RF-mai-2019.pdf Access in: 10 jun. 2019.

3 V. Appeal Court of La Haye, 18 déc. 2015 and the comments, C. BRIGHT, C. Quelques réflexions à propos de l'affaire Shell aux Pays-Bas. SFDI L'entreprise multinationale et le droit international, Pedone, 2016. p. 127.

4 See LLuiya v. RWE, currently before Appeal Court of Hamm (Germany). The case was admited (13 nov. 2017). See comments: http://blogs.law.columbia.edu/climatechange/2017/12/07/thehuaraz-case-lluiya-v-rwe-german-court-opens-recourse-to-climatelaw-suit-against-big-co2-emitter/ of companies should enable the courts, subject to certain conditions imposed by the various applicable laws, to find parent companies liable for the harm caused on foreign land by the activities of their subsidiaries.

What is this duty we are discussing here? In France, the devoir de vigilance is set out in the law of 27 March 2017, which requires certain French parent and subcontracting companies to draw up and implement a vigilance plan to prevent the occurrence of harm to the health and safety of employees and of human rights and environmental violations caused by their activities and those of their commercial partners 5 . In other legal systems, the courts have been the ones to recognise this duty. Thus, in common law systems, due diligence consists in a more general duty stemming from tort law rather than company law. On a closer look, as underlined by a number of authors, there are already some signs that reveal the willingness of common law judges to use this duty of care as a tool to demand from certain companies a more diligent conduct with regard to the risks created by their activities and those of their subsidiaries and, in the event of a breach, to find them liable.

This observation reminds us that, as a supplement or as a remedy to the shortcomings of legislators, the courts of all domestic legal orders do have the power to change the legal landscape and contribute to improving environmental justice. And, it must be pointed out that these evolutions of domestic laws, through the action of legislators (I) and of the courts (II), could be reinforced on contact with transnational law (III) and, thus, taking a global perspective of the law, contribute to improving the compensation of environmental harm.

\section{French law: the scope of a duty of vigilance established by the legislator}

In the event of environmental damage caused by the overseas subsidiary of a French group of companies, victims should act against the French parent company,

\footnotetext{
5 L. $\mathrm{n}^{\circ}$ 2017-399, 27 mars 2017, JO 28 mars 2017, texte $\mathrm{n}^{\circ}$ 1; S SCHILLER, S. Exégèse de la loi relative au devoir de vigilance des sociétés mères et entreprises donneuses d'ordre. LexisNexis, 2017. p. 622; DANIS-FATÔME, A.; VINEY, G. La responsabilité civile dans la loi relative au devoir de vigilance des sociétés mères et des entreprises donneuses d'ordre. Recueil Dalloz, Dalloz, 2017. p. 1610; B. PARANCE, B.; GROULT E. Regards croisés sur le devoir de vigilance et la duty of care. Journal du Droit International, 2018.
} 
supposed to be more robust than its subsidiaries to sustain their claim for compensation ${ }^{6}$. To do so, they must establish the French court's jurisdiction and seek the application of a legal rule suitable to find the parent company liable on the merits. That the French courts have jurisdiction is not an issue. Regulation (EC) $\mathrm{n}^{\circ} 1215 / 2012$ of 12 December 2012, Brussels I bis (on jurisdiction and the recognition and enforcement of judgments in civil and commercial matters) provides that the claimant may sue in the courts for the domicile of persons domiciled in a Member state (art. 4.1). And thus, is it possible for foreign victims to bring proceedings before a French judge when the parent company is domiciled in France. However, traditionally, even if jurisdiction is established, itfor the judge not to be able to rely on any French legal rule to find a defendant liable. It should be pointed out that, pursuant to article 4.1 of regulation $n^{\circ} 864 / 2007$ of 11 July 2007 (Rome II) on the law applicable to non-contractual obligations, in civil liability matters, the law applicable is the law of the country where the damage occurs. However, as an exception, article 7 of the regulation enables the victim, when environmental damage is involved, to choose between the law of the place where the damage occurred and the law of the place where the harmful event took place, in this case the head office of the parent company. Assuming that victims opt for the law of the harmful event, this makes no difference. Under French law, as in many other legal systems, because of the patrimonial autonomy of companies, the "group" does not constitute a legal entity and the "parent company" is not liable for the harmful actions of its subsidiaries? ${ }^{7}$ There is currently no general liability of a parent company for the actions of its subsidiaries. Admittedly, there are some exceptions ${ }^{8}$. The corporate veil can be lifted if the facts demonstrate a subsidiary's lack of patrimonial autonomy. A court may view the subsidiary as a mere fictitious company or, if this is not possible, rely on the theory of perception by third parties or the theory of interference by the parent company in the management of its subsidiary, in order to find such parent company

\footnotetext{
BOSKOVIC, O. Brèves remarques sur le devoir de vigilance et le droit international privé. Européen et international, 2016; La compétence des juridictions des pays source pour connaitre des actions intentées à l'encontre des entreprises multinationales, Dalloz, Point de vue, p. 732; Fascicule 146-30 Droit international privé et environnement, JurisClasseur Droit international, LexisNexis.

7 See Cass. Com. 15 nov. 2011, n 10-21.701.

8 See La responsabilité dans les groupes de sociétés, Actes pratiques et ingénierie sociétaire préc.
}

liable for the debt of its subsidiary. Here however, the conditions for lifting the veil are rarely met, and environmental matters are no exception?.

The entry into force of the law of 27 March 2017 was a game changer, not only for parent companies, but also subcontracting companies - and they can sometimes be both -, if they employ a certain number of employees (over 5,000 employees in France or 10,000 employees in France and abroad) and have their registered office in France. More specifically, these companies are now required to draw up and implement a vigilance plan. Pursuant to article L. 225-102-4-1, paragraph 3, of the French Commercial code, this plan "includes reasonable vigilance measures suitable to identify risks and prevent serious violations of human rights and fundamental freedoms as well as harm to the health and safety of individuals and to the environment, resulting from the activities of the company and those of the companies it controls within the meaning of paragraph II of article L. 233-16, directly or indirectly, as well as the activities of subcontractors or suppliers with whom an established commercial relationship exists, when these activities are linked to this relationship" ${ }^{10}$. Should companies fail to comply, the legislator has specifically provided that they shall be directly liable, in accordance with the general rules of civil liability, for the damage that the performance of these obligations would have avoided (article L. 225-102-5 of the Commercial code).

We see how this mechanism could be of interest in the context of a transnational dispute. The vigilance plan includes the activities of a company's overseas subsidiaries, subcontractors and suppliers. The French duty of vigilance has an extraterritorial reach. Hence, in the future, a French transnational company could find itself before a court to answer for environmental harm caused in a foreign country if such harm could have been avoided by the effective implementation of a vigilance plan imposed pursuant to the new French duty of vigilance. It is true that the scope of this duty of vigilance remains limited. Besides the fact that it does not apply to all large corporations, the doctrine highlights how difficult it would be to prove the causal link between a breach of the duty of vigilance and the damage involved ${ }^{11}$. In that case, reverting back to general rules

\footnotetext{
HANNOUN, C. La responsabilité environnementale des sociétés mères. Revue Environnement, 2009.

10 Our translation.

11 A. Danis-Fâtome et G. Viney, art. préc.
} 
of civil liability, a court would have to determine whether, on the basis of its personal responsibility, the parent company may have committed a fault that resulted in the damage caused by its subsidiary. However, like certain foreign judges when applying the duty of care that exists in common law systems, the courts' power of interpretation could enable them to bring about certain evolutions.

\section{Common law: the scope of a duty of care construed by the courts}

As under French law, under Common Law, there is no vicarious liability of parent companies for the harm caused by their subsidiary. However, they can be found directly liable for negligence if there is a pre-existing duty of care, a duty owed by certain persons towards other natural or legal persons because of their proximity ${ }^{12}$.

Each jurisdiction carries its own interpretation. For example, in England, the establishment by a court of a duty of care depends on the assessment of three elements stemming from the ruling in Caparo Industries plc/ Dickman $^{13}:$ 1) the foreseeability of the damage caused to the claimant, 2) the proximity between the claimant and the defendant, and 3) that it is fair, just and reasonable to impose a duty of care in light of the facts of the case or of the wider political context. If all these elements are satisfied, the company can potentially incur liability for lack of due diligence if damage occurs. This is how, in the case of Chandler v/ Cape dated 25 April 2012 ${ }^{14}$, an English court found a British parent company liable for the health-related damage suffered by the employees of its subsidiary because of the activities of the latter, after considering that, not only did the parent company know of the risks caused by the activities of its subsidiary (foreseeability), but also, there were policies applicable in relation to health issues that applied to the whole group, and it was fair, just and reasonable for the parent company to owe a duty of care in this respect ${ }^{15}$.

\footnotetext{
12 Not. R.-C. Drouin, art. préc.

13 Case rendered By House of Lords in 1990, 2 A.C. 605. https:/ / papers.ssrn.com $/$ sol3 $/$ papers.cfm ?abstract_id $=2626806$

${ }_{14}$ Court of Appeal R.U., 25 avril 2012. See H. Muir Watt, Revue critique de droit international privé, 2013, p. 632.

15 Sur ce rappel M.-C. DROUIN, R.C. Le développement du contentieux à l'encontre des entreprises transnationales: quel rôle pour
}

A review of the case law shows that, on several occasions, by making a detour via the substantial conditions governing liability in order to rule on matters of jurisdiction, a number of judges, in particular English, Dutch and Canadian judges ${ }^{16}$, appear to be ready to accept the liability of parent companies for the environmental harm caused by their subsidiaries.

On the English side, the ruling in Dominic Liswaniso Lungowe v/ Vedanta Ressources by the UK's Court of Appeal on 13 October 2017 and by the Supreme Court on 10 April $2019^{17}$ is topical. In this case, a group of Zambian victims brought proceedings in respect of discharges of harmful substances due to the mining activity of the Zambia-based subsidiary of parent company Vedanta Ressources ${ }^{18}$. To accept jurisdiction, the court accepted that the liability of the parent company could be envisaged based on the applicable law, in that instance Zambian law, which is derived from common law and identical to English law. Thus, it is by expanding its approach, not only to cases of property, physical and environmental damage suffered by third parties - beyond employees -, but also to cases of damage caused by overseas subsidiaries, that the court accepted its jurisdiction with regard to a subsidiary, in addition to the parent company.

As for the Netherlands, it was in the Shell decision that a Dutch court accepted jurisdiction with regard to Royal Dutch (Shell) and its Nigerian subsidiary. This case involved a lawsuit brought by Nigerian farmers who sought compensation for environmental harm (soil and water contamination from oil spills) and human rights violations ${ }^{19}$. To support their claim, the victims had argued that the law applicable to the merits of the case was Nigerian law, which is based on common law and thus recognises a duty of care. Pointing to the

le devoir de vigilance? Droit social, 2016. p. 246.

16 About this evolution see : H. Muir Watt, « Compétence du juge anglais en matière de responsabilité de la société mère pour les dommages causés par sa filiale à l'étranger ", Revue critique de droit international privé 2017, p. 613 ; R.-C. Drouin, art. préc. ; SAUMIER, G. L'ouverture récente des tribunaux canadiens aux poursuites dirigées contre les sociétés mères pour les préjudices causés par leurs filiales à l'étranger. Revue critique de droit international privado, 2018. p. 775.

17 Vedante Resources PLC and another v Lungowe and others, 2019, UKSC 20.

18 Royal Court of Justice, 13 oct. 2017, v. http://www.bailii.org/ ew/cases/EWCA/Civ/2017/1528.html

19 BRIGHT, C. Quelques réflexions à propos de l'affaire Shell aux Pays-Bas. SFDI L'entreprise multinationale et le droit international, Pedone, 2016. p. 127. 
potential liability of a parent company on the basis of the decision in Chandler v. Cape, the Dutch court was able to accept jurisdiction.

Lastly, we must highlight the importance of the Canadian court in the case of Choc c./ Hudbay Minerals Inc, ruled on by the Ontario Superior court in 2013 and involving, once again, a mining company ${ }^{20}$. Although the claimants located on Guatemalan soil (members of an indigenous Mayan population) were seeking remedy for human rights violations caused by the security personnel of the subsidiary of Canadian company Hudbay, the reasoning is transposable to environmental cases. In this instance, when ruling on the admissibility of the claim, the court found that the parent company could potentially be found liable because the three criteria necessary for the establishment of a duty of case were satisfied.

These cases do not change the fact that, when it comes to the merits of a case, a court may decide not to sanction a parent company. Hence, in the Shell case, in the end, the court found, for reasons of opportunity, justice and equity, that the company had not breached its duty of care ${ }^{21}$. However, by contemplating the potential liability of parent companies in order to accept jurisdiction, judges show that the concept of a duty of care is a very malleable standard that could enable them to take the leap and actually find a company liable. This is all the more compelling that, when taking a closer look at this line of cases, we see that this standard is bound to evolve on contact with the conduct, within the transnational order, of corporations themselves.

\section{The transnational order: the scope of a duty of care accepted by corporations}

The duty of care or vigilance also finds its source in various instruments stemming from the transnational non-state - order which, as part of the normative world of CSR (corporate social responsibility), call for companies to exercise due diligence by acting within their "sphere of influence" to prevent human rights violations and harm to the health and safety of workers and

\footnotetext{
20 Choc c/ Hudbay minerals, Superior Court of Ontario, CV-10411159, Judge Master Graham, 29 juin 2013.

21 Tribunal District La Haye, 30 janvier 2013 et Appeal Court La Haye, 18 déc. 2015 :
}

to the environment ${ }^{22}$. Thus, it is included in the OECD Guidelines for multinational enterprises ${ }^{23}$, in the ISO 26000 standard providing guidance on social responsibility of organisations published in November 2010 and in the guiding principles on business and human rights (drawn up by John Ruggie, the Special representative of the secretary general on human rights and transnational corporations and other business enterprises and approved by the Human Rights Council in its resolution $17 / 4$ of 16 June 2011$)^{24}$. Although these are voluntary commitments, still, when companies adhere to them, they agree to implement the various recommendations and, to do so, to take measures allowing them to ensure that their activities do not cause harm, in particular to human rights and to the environment. To achieve this, they can, for instance, adopt codes of good practice or impose sustainable development clauses in certain agreements entered into with their suppliers.

Now, couldn't the courts rely on these voluntary commitments to establish the existence of a duty of care pursuant to tort law, or of a faute civile in a civil law context? Couldn't these commitments lead to a renewed interpretation of the duty of care capable of making parent companies liable if damage is caused by their subsidiaries and, ultimately, other commercial partners? Since the duty of care is a standard, its content is bound to evolve in parallel with social transformations and with what is "normally expected" today from a transnational enterprise. An increasing number of authors support this and consider that it is how CSR could be grasped by the law ${ }^{25}$. In practical terms, the idea is as follows: in addition to the fact that companies that

\footnotetext{
22 See S. Schiller (dir.), Le devoir de vigilance, LexisNexis, 2019. 23 http://www.oecd.org/fr/investissement/mne/2011102-fr.pdf 24 http://www.ohchr.org/Documents/Issues/Business/IntroductionsGuidingPrinciples_fr.pdf

${ }^{25}$ See R. de QUENAUDON, R.; MARTIN-CHENUT, K. La RSE saisie par le droit. Paris: Pedone, 2016.; ABADIE, P. Le juge et la responsabilité sociale de l'entreprise. Recueil Dalloz, n. 6, p. 302-308, 2018 ; v. aussi, I. DESBARATS, I. La RSE à la française, où en est-on? Droit social, 2018. p. 525 ; P. Deumier, " La réception du droit souple par l'ordre juridique », in Le droit souple, Association Henri Capitant, coll. Thèmes et commentaires Dalloz 2009, p. 122 ; Responsabilité sociale des entreprises, Répertoire Dalloz Sociétés, F.G. Trébulle ; M.P. BLIN, M. P; DESBARATS, I.; JAZOTTES G.; VIDALENS, V. Entreprise et développement durable: approche juridique pour l'acteur économique du XIXe siècle. Revue juridique de l'Environnement, v. 2, p. 403-404, 2011. p. 120. V. aussi M. HAUTEREAU-BOUTONNET, M. Une illustration du droit global, la lex mercatoria climatique. Brazilian Journal of International Law, v. 14, 2017. Available in: https://www.publicacoesacademicas.uniceub.br/rdi/ article/view/4998 Access in: 10 jun. 2019.
} 
commit to adopting a diligent approach with regard to the risks created directly or indirectly by their activities, could be blamed for wrongful conduct if damage occurred as a result of the non-observance of their commitments, more generally, the multiplication of these voluntary commitments could be the manifestation of a new custom applicable to all transnational enterprises, on which courts could rely to assess the various criteria surrounding the common law concept of a duty of care and civil law concept of a faute.

The first signs of this can already be seen.

In France, already, in the Erika case that led to Total incurring liability for the environmental harm caused by the tanker it had chartered, the French judge did not hesitate to rely on voluntary norms to assess the criminal wrongdoing of the company ${ }^{26}$. While the control exercised over its subsidiary was deduced from the terms of the charter-party imposing certain diligence practices in favour of the parent company, the failure of this control was assessed in light of the vetting rules (a preventive contractual instrument in maritime transport law) put in place at the request of the parent company itself. And, more importantly, the Paris Court of appeal, in a ruling dated 19 December 2013, did not hesitate to consider a director's wrongdoing, stating that "an increasing number of investors are focused on "engagement" (...)" and "that a listed company cannot ignore its shareholders' practices which today are considered 'normal"' 27 . Thus, as a result of common practices emerges a requirement imposing a conduct that is normally expected from enterprises with regard to risk management.

As for foreign courts, while traces do appear in the Vedanta jurisprudence, it was mostly in the aforementioned Hudbay case that the judge underlined the importance of the various public commitments made by the parent company. Some had to do with the standards of conduct applicable to its security guards, others related to human rights, such as the subscription to the voluntary principles regarding security and human rights. Furthermore, in the Shell decision, in order to accept jurisdiction, the court did not hesitate to highlight that the duty of care owed by the parent company was justified by the fact that the latter acknowledged it by adopting

\footnotetext{
26 Cass. 25 septembre 2012, n $10-82938$.

27 Paris, 19 déc. 2013, nº 12/22644, Rev. Sociétés 2014, p. 306, comments A. Viandier. [Our translation]
}

certain voluntary commitments towards the prevention of environmental harm, such as codes of good practice. And at that point, the court even suggested that in the next stage of the appeal, the court should consider, in light of various issues, whether these voluntary commitments had in fact led to the adoption of certain mechanisms, the absence of which would prove wrongdoing. Thus, as explained by Renée-Claude Drouin, these commitments provide a basis for the demonstration, altogether, of the foreseeability of the damage, of the existence of a certain degree of proximity with third parties, and of the politically acceptable nature of this duty of care.

This study thus reveals that it is through a combination and a convergence of state and non-state, hard and soft, both imposed and voluntarily accepted, laws, that the duty of care of transnational companies as recognised in the various legal orders could become an essential tool for the compensation of environmental harm.

\section{References}

ABADIE, P. Le juge et la responsabilité sociale de l'entreprise. Recueil Dalloz, n. 6, p. 302-308, 2018.

BLIN, M. P; DESBARATS, I.; JAZOTTES G.; VIDALENS, V. Entreprise et développement durable: approche juridique pour l'acteur économique du XIXe siècle. Revue juridique de l'Environnement, v. 2, p. 403-404, 2011.

BOSKOVIC, O. Brèves remarques sur le devoir de vigilance et le droit international privé. Européen et international, 2016.

BRIGHT, C. Quelques réflexions à propos de l'affaire Shell aux Pays-Bas. SFDI L'entreprise multinationale et le droit international, Pedone, 2016.

DANIS-FATÔME, A.; VINEY, G. La responsabilité civile dans la loi relative au devoir de vigilance des sociétés mères et des entreprises donneuses d'ordre. Recueil Dalloz, Dalloz, 2017.

DESBARATS, I. La RSE à la française, où en est-on? Droit social, 2018.

DROUIN, R.C. Le développement du contentieux à l'encontre des entreprises transnationales: quel rôle pour le devoir de vigilance? Droit social, 2016. 
HANNOUN, C. La responsabilité environnementale des sociétés mères. Revue Environnement, 2009.

HAUTEREAU-BOUTONNET, M. Une illustration du droit global, la lex mercatoria climatique. Brazilian Journal of International Law, v. 14, 2017. Available in: https:// www.publicacoesacademicas.uniceub.br/rdi/article/ view/4998 Access in: 10 jun. 2019.

HAUTEREAU-BOUTONNET, M.; TRUILHÉ, E. Le procès environnemental, du procès sur l'environnement au procès pour l'environnement, soutenu par la Mission de Recherche Droit et Justice, 2019. Available in: http://www.gip-recherche-justice.fr/wp-content/ uploads/2019/05/16.31-RF-mai-2019.pdf Access in: 10 jun. 2019.

MUIR WATT, H. Compétence du juge anglais en matière de responsabilité de la société mère pour les dommages causés par sa filiale à l'étranger. Revue critique de droit international privé, 2017.
PARANCE, B.; GROULT E. Regards croisés sur le devoir de vigilance et la duty of care. Journal du Droit International, 2018.

QUENAUDON, R.; MARTIN-CHENUT, K. La RSE saisie par le droit. Paris: Pedone, 2016.

SAUMIER, G. L'ouverture récente des tribunaux canadiens aux poursuites dirigées contre les sociétés mères pour les préjudices causés par leurs filiales à l'étranger. Revue critique de droit international privado, 2018.

SCHILLER, S. Exégèse de la loi relative au devoir de vigilance des sociétés mères et entreprises donneuses d'ordre. LexisNexis, 2017.

TRÉBULLE, F. G. Responsabilité sociale des entreprises. Repère Dalloz Sociétés, 2003. 
Para publicar na Revista de Direito Internacional, acesse o endereço eletrônico www.rdi.uniceub.br ou www.brazilianjournal.org.

Observe as normas de publicação, para facilitar e agilizar o trabalho de edição. 